\title{
New records of Atractus ronnie (Serpentes, Colubridae) in relictual forests from the state of Ceará, Brazil, and comments on meristic and morphometric data
}

\author{
Daniel Loebmann ${ }^{1 *}$ \\ Samuel Cardozo Ribeiro ${ }^{2}$ \\ Débora Lima Sales ${ }^{2}$ \\ Waltécio de Oliveira Almeida ${ }^{2}$ \\ ${ }^{1}$ PPG em Zoologia, Instituto de Biociências, Universidade Estadual Paulista \\ Av. 24 A, 1515, Bairro Bela Vista, CEP 13506-900, Rio Claro - SP, Brazil \\ ${ }^{2}$ Departamento de Química Biológica \\ Universidade Regional do Cariri, Crato - CE, Brazil \\ *Author for correspondence \\ waltecio@gmail.com
}

Submitted on $09 / 04 / 2008$

Accepted for publication on $11 / 11 / 2008$

\section{Resumo}

Novos registros de Atractus ronnie (Reptilia, Serpentes, Colubridae) em florestas relictuais do estado do Ceará e comentários sobre dados merísticos e morfométricos. Atractus ronnie foi recentemente descrita para Serra de Baturité, uma área montanhosa de enclave de floresta relictual na Caatinga semi-árida, estado do Ceará, nordeste do Brasil. Apresentamos aqui novos registros de $A$. ronnie em duas novas áreas de floresta relictual e apresentamos dados adicionais de variação de sua folidose. Os resultados apresentados aqui reforçam a necessidade de inventários sistemáticos em florestas relictuais do Ceará, uma vez o conhecimento sobre a herpetofauna das florestas relictuais permanece pobremente conhecido.

Unitermos: Atractus ronnie, Colubridae, nordeste do Brasil, florestas relictuais, estado do Ceará

\section{Abstract}

Atractus ronnie was recently described from Serra de Baturité, a mountainous relictual forest enclave in the semiarid Caatinga, state of Ceará, northeastern Brazil. Here we report new records of $A$. ronnie in two other areas of relictual forests and provide additional data on pholidosic variation. The results presented herein reinforce the need for systematic inventory surveys in the relictual forests of Ceará, since the herpetofauna remains poorly known.

Key words: Atractus ronnie, Colubridae, northeastern Brazil, relictual forests, Ceará state 
The genus Atractus currently comprises about 100 species of semi-fossorial or fossorial snakes (Fernandes et al., 2000; Passos et al., 2005) widely distributed in South and Central America, occurring from southern Panama to Argentina (Giraudo and Scrocchi, 2000; Myers, 2003). A total of 29 species of Atractus are recognized for Brazil (SBH, 2008), with only Atractus guentheri (Wucherer, 1861), Atractus maculatus Günther, 1858, Atractus potschi Fernandes, 1995, and the recently described Atractus ronnie Passos, Fernandes \& Borges-Nojosa, 2007 occurring in northeastern Brazil (Fernandes, 1995; Fernandes, 1996; Passos et al., 2007).

Atractus ronnie (Figure 1) has recently been described on the basis of individuals from Serra de Baturité (Baturité hills), a mountainous humid forest in the semiarid Caatinga domain, state of Ceará, Brazil (Passos et al., 2007). Here we report two new records of $A$. ronnie in the state of Ceará and provide additional data on the pholidosic variation of this taxon.
The first record was a single specimen from the Plateau of Ibiabapa, municipality of Tianguá $\left(03^{\circ} 43^{\prime} 7.02^{\prime \prime} \mathrm{S}, 40^{\circ} 55^{\prime} 53.71^{\prime} \mathrm{W}, 871 \mathrm{~m}\right.$ above sea level). The second record consisted of specimens from the Plateau of Araripe, municipality of Crato $\left(07^{\circ} 15^{\prime} 19^{\prime \prime} \mathrm{S}, 39^{\circ} 28^{\prime} 12^{\prime \prime} \mathrm{W}\right.$, at $729 \mathrm{~m}$ above sea level). Voucher specimens were deposited at the Laboratory of Zoology, Universidade Regional do Cariri (LZURCA 460-465; 489-491) and Museu Nacional, Universidade Federal do Rio de Janeiro (MNRJ 17326).

Both areas are relictual forests and represent exceptionally humid habitat islands within the semiarid Caatinga Domain (sensu Ab'Saber, 1977). Localized orographic rains and fog condensation favor the persistence of these relictual forests, and they experience significantly milder temperatures and increased levels of rainfall compared to the surrounding Caatinga lowlands (Vanzolini, 1981; Andrade-Lima, 1982; Carnaval and Bates, 2007). The main difference between both areas is the location of the relictual forest. This happens because the chemical

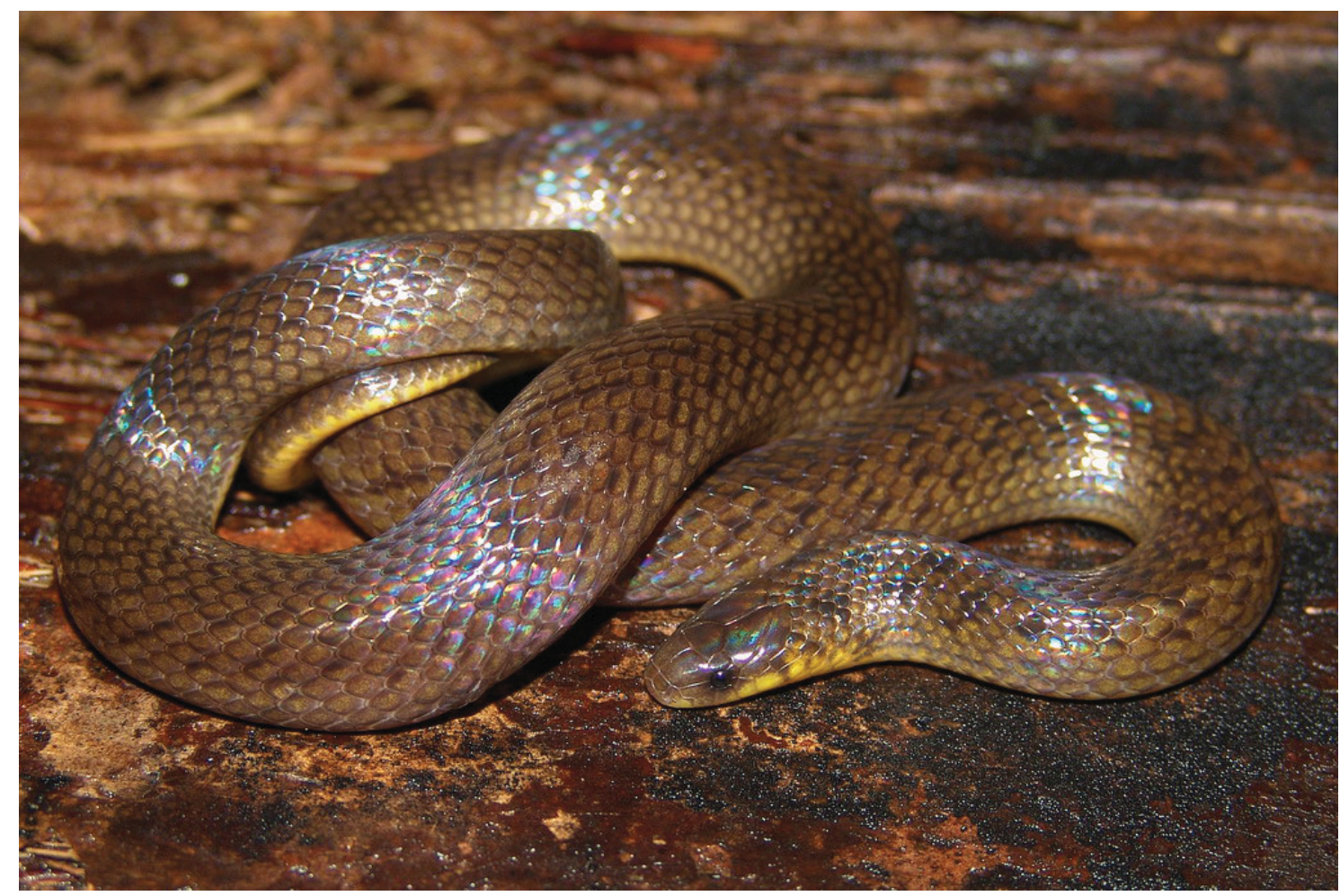

FIGURE 1: General view of the adult female of Atractus ronnie in life collected in the municipality of Tianguá, Plateau of Ibiapaba. Picture by Daniel Loebmann. 
morphogenesis which contributes to the formation of the humid forest occurs on the tops and slops of the hills on the Plateau of Ibiapaba, while on the Plateau of Araripe this phenomenon occurs only on the slopes of the hills (Fernandes, 1990).

Meristic data from the collected specimens agree in most aspects with the original description, although it is possible to identify certain differences (Table 1). The maximum snout vent lengths attained by specimens, especially among females, were greater $(223 \mathrm{~mm}$ in males; $391 \mathrm{~mm}$ in females) than those seen among individuals from Serra de Baturité (220 $\mathrm{mm}$ in males; $312 \mathrm{~mm}$ in females). Although the ventral color pattern is uniformly creamish white in most of the specimens analyzed, as depicted in the original description, the largest specimen had small dark brown spots concentrated in the distal half of its body.

Scale counts also revealed certain differences. Ventral scales varied from 146 to 163 among females $(\mathrm{n}=7)$, and from 129 to 132 among males $(\mathrm{n}=3)$, against 154-160 among females and 134-144 among males in the original description. Subcaudals were very similar to the original description, although one female had 16 subcaudals, one less than the minimum observed in the population of Serra de Baturité.

Although some of the meristic data differ from the original description we believe these must be interpreted as intraspecific variations rather than to consider these populations as a distinct taxon.

The presence of $A$. ronnie in other areas of relictual forest in Ceará demonstrates that the species is not restricted to Serra de Baturité. The new records presented here extend the species distribution by ca. $230 \mathrm{~km}$ east and ca. $350 \mathrm{~km}$ south from the type locality, the municipality of Pacoti, state of Ceará (Figure 2).

These results provide additional evidence for the need of systematic inventory surveys in order to study the diversity of the herpetofauna of the relictual forests of Ceará state, since new distribution records and new taxa continue to be published in recent years (e.g. Loebmann et al., 2007; Passos et al., 2007; Loebmann, 2008a; 2008b; 2008c; Ribeiro et al., 2008).

TABLE 1: Measurements and scale counts from all individuals of Atractus ronnie examined in this study. PAHF $=$ Plateau of Araripe (humid forest); PIHF $=$ Plateau of Ibiapaba (humid forest); SVL $=$ Snout Vent Length; $\mathrm{CL}=$ Caudal Length; VSN = Ventral Scale Number; SSN = Subcaudal Scale Number.

\begin{tabular}{cccccccc}
\hline Local & Sex & SVL $(\mathbf{m m})$ & CL $(\mathbf{m m})$ & VSN & SSN & Sample method & Voucher number \\
\hline PAHF & Male & 223 & 30 & 132 & 22 & Pitfall & LZ-URCA 465 \\
PAHF & Male & 204 & 28 & 129 & 23 & Pitfall & LZ-URCA 462 \\
PAHF & Male & 203 & 27 & 132 & 24 & Pitfall & LZ-URCA 463 \\
PAHF & Female & 284 & 29 & 151 & 20 & Pitfall & LZ-URCA 464 \\
PAHF & Female & 247 & 26 & 152 & 20 & Pitfall & LZ-URCA 460 \\
PAHF & Female & 247 & 25 & 146 & 17 & Pitfall & LZ-URCA 489 \\
PAHF & Female & 241 & 21 & 149 & 19 & Pitfall & LZ-URCA 491 \\
PAHF & Female & 234 & 20 & 149 & 16 & Pitfall & LZ-URCA 490 \\
PAHF & Female & 217 & 19 & 146 & 18 & Pitfall & LZ-URCA 461 \\
PIHF & Female & 391 & 33 & 163 & 23 & Visual search & MNRJ 17326 \\
\hline
\end{tabular}




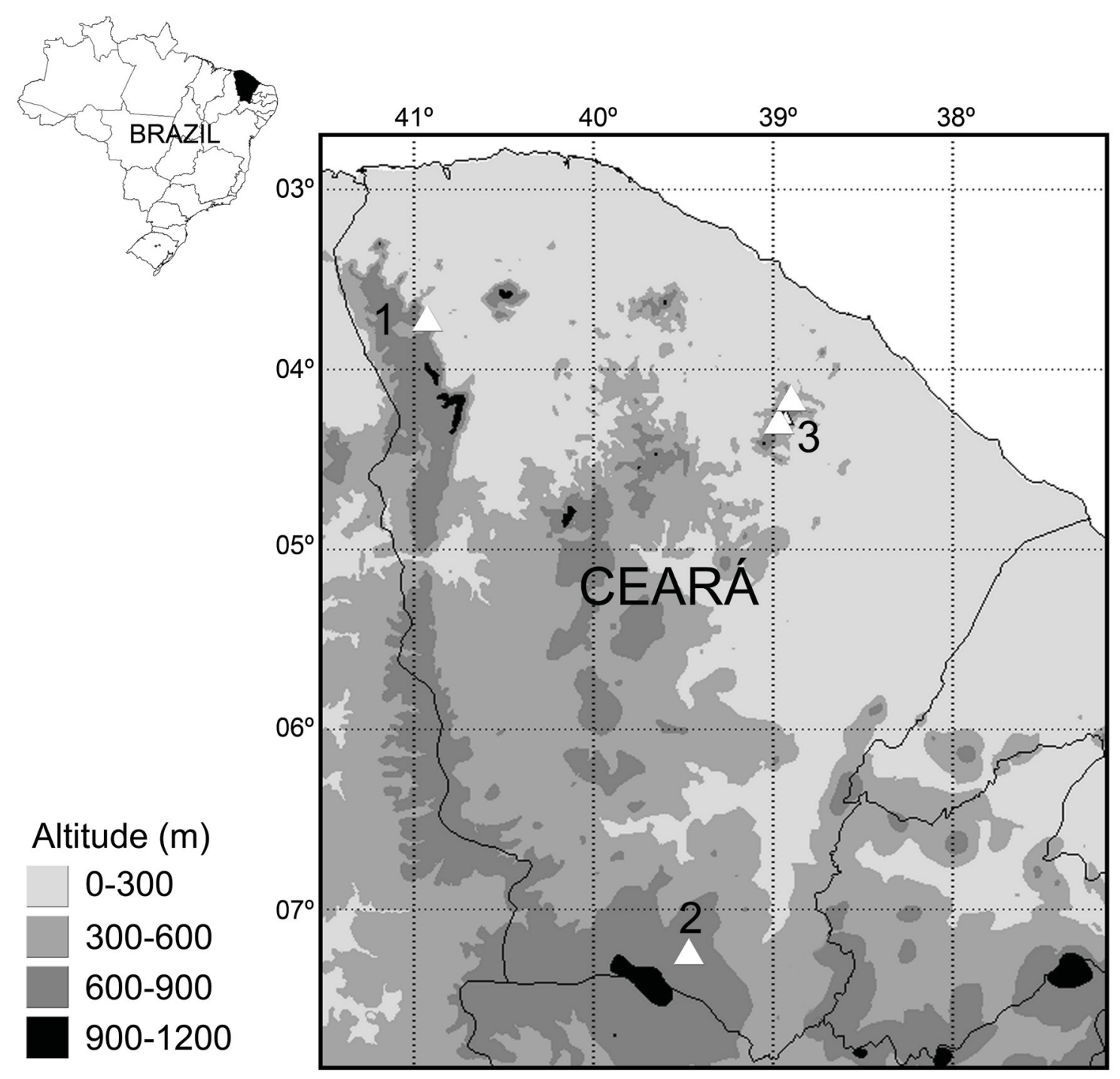

FIGURE 2: Geographic distribution of Atractus ronnie (white triangles). 1 - Plateau of Ibiapaba; 2 - Plateau of Araripe; 3 - Serra de Baturité.

\section{Acknowledgments}

The authors are grateful to the Instituto Brasileiro do Meio Ambiente e dos Recursos Naturais Renováveis (IBAMA) for permission to collect specimens (Processes 14.130-1 and 267/2006). We also thank Raimundo M. de Almeida and his family for logistical support during the field work in the municipality of Crato. Adaílton D. da Silva and Igor Joventino Roberto helped us in the field work. DL is supported by grant $\mathrm{n}^{\mathrm{o}} 140226 / 2006-0$ from the Conselho Nacional de Pesquisa e Desenvolvimento (CNPq). We are grateful to the Fundação Cearense de Apoio ao Desenvolvimento Científico e Tecnológico - FUNCAP for our research grant (Process number
9913/06 - Contract 0006-00/2006) the scholarship awarded to SCR, and the productivity fellowship of WOA (02/2008-BPI), and to the Brazilian National Research Council - CNPq for its support through a PIBIC scholarship to DLS.

\section{References}

Ab’ Saber, A. N. 1977. Os domínios morfoclimáticos na América do Sul. Primeira aproximação. Geomorfologia, 52: 1-21.

Andrade-Lima, D. 1982. Present-day refuges in northeastern Brazil. In: Prance, G. T. (Ed.). Biological diversification in the tropics. Columbia University Press, New York, USA, p.245-251. 
Carnaval, A. C.; Bates, J. M. 2007. Amphibian DNA Shows Marked Genetic Structure and Tracks Pleistocene Climate Change in Northeastern Brazil. Evolution, 61 (12): 2942-2957.

Fernandes, A. 1990. Temas Fitogeográficos. Editora Stylus Comunicações, Fortaleza, Brazil, 116pp.

Fernandes, R. 1995. A new species of snake in the genus Atractus (Colubridae: Xenodontinae) from northeastern Brazil. Journal of Herpetology, 29: 416-419.

Fernandes, R. 1996. Variation and taxonomy of Atractus reticulatus complex (Serpentes: Colubridae). Comunicações do Museu de Ciências e Tecnologia da PUCRS (Série Zoologia), 8: 37-53.

Fernandes, R.; Freire, E. M. X.; Puorto, G. 2000. Geographic variation of the Brazilian Atlantic Rainforest snake Atractus maculatus (Günther, 1858), with revalidation of Rhabdosoma zebrinum Jan, 1862 (Serpentes: Colubridae). Boletim do Museu Nacional, Nova Série, Zoologia, 419: 1-8.

Giraudo, A. R.; Scrocchi, G. J. 2000. The genus Atractus (Serpentes: Colubridae) in Northeastern Argentina. Herpetological Journal, 10: 81-90.

Loebmann, D. 2008a. Geographic distribution. Echinanthera affinis. Brazil: Ceará. Herpetological Review, 39 (2): 241.

Loebmann, D. 2008b. Geographic distribution. Mesoclemmys perplexa. Brazil: Ceará. Herpetological Review, 39 (2): 236.

Loebmann, D. 2008c. Geographic distribution. Typhlops brongersmianus. Brazil: Ceará. Herpetological Review, 39 (2): 244.
Loebmann, D.; Prado, C. A. P.; Haddad, C. F. B.; Bastos, R. F. Guimarães, L. D. 2007. Geographic distribution. Hypsiboas multifasciatus, Brazil: Ceará and Goiás. Herpetological Review, 38: 476.

Myers, C. W. 2003. Rare snakes - five new species from eastern Panama: Reviews of Northern Atractus and Southern Geophis (Colubridae: Dipsadinae). American Museum Novitates, 3391: 1-47.

Passos, P.; Fernandes, R.; Zanella, N. 2005. A new species of Atractus (Serpentes: Colubridae) from Southern Brazil. Herpetologica, 61: 209-218.

Passos, P.; Fernandes, D. S.; Borges-Nojosa, D. M. 2007. A new species of Atractus (Serpentes: Colubridae: Dipsadinae) from a relictual forest in Northeastern Brazil. Copeia, 2007: 788-797.

Ribeiro, S. C.; Ferreira, F. S.; Brito, S. V.; Santana, G. G.; Vieira, W. L. S.; Alves, R. R. N.; Almeida, W. O. 2008. The Squamata fauna of the Chapada do Araripe, Northeastern Brazil. Cadernos de Cultura e Ciência, 3 (2): 27-40.

SBH. 2008. Brazilian reptiles/List of species - an on line reference. Accessible at $<\mathrm{http}: / /$ www.sbherpetologia.org.br $>$. Accessed on 30 May 2008.

Vanzolini, P. E. 1981. A quasi-historical approach to the natural history of the differentiation of reptiles in tropical geographic isolates. Papéis Avulsos de Zoologia, 34: 189-204. 